\title{
A Combination of Tightening Exercises and Aerobics for Patients with Diabetes Mellitus in Health Center 1 West Denpasar
}

\author{
Tanjung Subrata, Asri Lestarini, Ni Luh Putu Eka Kartika Sari \\ \{asrilestarini@gmail.com\} \\ Warmadewa University, Bali, Indonesia
}

\begin{abstract}
The prevalence of diabetes mellitus (DM) in Bali is expected to continuously increase along with changes in lifestyle and dietary habits of people, including those living in Denpasar City. The empowerment of partners, namely the Diabetes Group of the Rahajeng Garjita Community in Health Center 1 West Denpasar, aims to improve the exercise understanding and skills in order to help control patients' blood sugar levels to prevent complications in diabetes mellitus. The method used to achieve these objectives is counseling, training and assistance on diet, as well as exercise and control of blood sugar levels specifically for people with diabetes mellitus until it is independently applied by partners and the community. HbAlc examination before and after exercise is carried out to determine changes in the patient's blood sugar control. The results showed that the mean $\mathrm{HbAlc}$ before and after exercise were 6.83 and 6.78 percent, respectively. Therefore, it was concluded that there was a decrease in patients $\mathrm{HbAlc}$ level by $0.73 \%$ in the combination exercise. Therefore, health services for DM patients need to include combination exercise in their programs.
\end{abstract}

Keywords: combination of tightening exercises, diabetes group, West Denpasar.

\section{Pendahuluan}

Paguyuban Rahajeng Garjita yang merupakan perkumpulan pasien diabetes melitus sewilayah Puskesmas 1 Denpasar Barat. Puskesmas I Denpasar Barat secara administratif terdiri dari 3 Desa dan 2 Kelurahan yaitu: Desa Padang Sambian Kaja, Kelurahan Padang Sambian, Desa Tegal Kerta, Desa Tegal Harum dan Kelurahan Pemecutan. Sedangkan jumlah total banjar di wilayah kerja Puskesmas I Denpasar Barat sebanyak 63 Banjar. Batas-batas wilayah Puskesmas 1 Denpasar Barat yaitu sebelah utara: Kelurahan Sempidi dan Desa Pemecutan Kaja, sebelah selatan: Desa Padang sambian Kelod, sebelah timur: Desa Pemecutan Kelod; sebelah barat: Desa Kerobokan, Kuta Utara.

Mengingat perkembangan kawasan perkotaan yang demikian pesat, dengan tingkat hunian penduduk yang padat telah mempengaruhi pola hidup masyarakat. Pergeseran budaya hidup masyarakat di era modern membuat masyarakat terancam oleh penyakit tidak menular. Salah 
satunya adalah diabetes mellitus yang menyumbang banyak angka kematian, bukan hanya di perkotaan, akibat perubahan gaya hidup, masyarakat pedesaan kini juga tidak dapat terhindar dari penyakit yang sering disebut kencing manis itu.

Diabetes Melitus (DM) merupakan salah satu penyakit metabolik yang ditandai dengan peningkatan kadar gula dalam darah (hiperglikemia) yang disebabkan karena kelainan sekresi insulin atau kerja insulin dan bisa juga diakibatkan oleh kedua faktor tersebut. DM umumya dibagi menjadi dua yaitu DM yang dikarenakan kekurangan absolut insulin endogen akibat destruksi autoimun pada sel beta pankreas (DM tipe I), sedangkan DM tipe II ditandai dengan resistensi insulin perifer dan gangguan sekresi insulin (American Diabetes Association, 2015).

Penyakit degeneratif yang disebut-sebut sebagai penyakit masyarakat perkotaan kini telah merambah ke desa-desa. Perubahan perilaku membuat mereka yang tinggal di pedesaan pun tak dapat terhindar dari diabetes, penyakit tidak menular yang menyumbang banyak angka kematian ini. Jumlah penyakit diabetes baik di desa maupun di kota memiliki angka yang hamper merata. Penyebabnya adalah perilaku hidup masyarakat yang sudah bergeser. Tercatat dari data Dinas Kesehatan Provinsi Bali bahwasannya jumlah kasus penderita diabetes pada 2011 di Bali tercatat 2.210 orang yang tersebar pada semua kabupaten/kota di Pulau Dewata (Dinas Kesehatan Provinsi Bali, 2012). Dari sembilan kabupaten/kota di Bali, kasus yang menonjol terjadi di Kabupaten Badung, Kabupaten Gianyar, dan Kota Denpasar, dimana wilayah Puskesmas Denpasar Barat yang merupakan daerah perkotaan bagian dari Kota Denpasar. Tingginya jumlah penderita diabetes di daerah perkotaan tidak terlepas dari gaya hidup dan pola makan masyarakat setempat. Tampaknya telah terjadi relevansi antara tingkat penghasilan dengan pola makan. Menurut data terbaru, kedatangan wisatawan mancanegara (wisman) ke Bali pada bulan Februari 2015 mencapai 338.991 orang (BPS, 2017). Pelaku wisata di daerah Bali semakin meningkat dari tahun ke tahun, begitu pula di daerah Denpasar. Pelaku industri wisata tentunya akan terpengaruh oleh pola makan dan gaya hidup Barat sehingga berdampak pada kesehaan masyarakat. Diketahui bahwa prevalensi DM di Bali 5 tahun terakhir mencapai lebih dari $6 \%$ dan diperkirakan jumlah ini akan terus meningkat seiring dengan perubahan gaya hidup dan pola makan masyarakat. Hal yang sama ditemukan di Puskesmas Denpasar Barat dimana terjadi peningkatan jumlah penderita diabetes. (Dinas Kesehatan Kota Denpasar, 2015).

Program kemitraan ini juga didasari oleh keberhasilan program serupa pada daerah lain yaitu di Puskesmas Denpasar Selatan (Subrata, 2018) dan Puskesmas Denpasar Timur. Perlu dilakukan program lanjutan sehingga dapat menyebarluaskan ipteks ini kepada masyarakat di daerah yang baru yaitu Puskesmas Denpasar Barat.

\section{Metode Pemecahan Masalah.}

\subsection{Penyuluhan}

Kegiatan ini dilakukan dengan mengumpulkan anggota kelompok diabetes dan petugas kesehatan untuk mengikuti penyuluhan tentang diabetes, diet dan exercise-nya. Beberapa materi yang akan diberikan meliputi: diabetes, pengelolaannya, peran diet dan exercise dalam menurunkan kadar gula darah, pentingnya pengendalian kadar gula darah dan cara pengukuran kadar gula darah mandiri. Penyuluhan dan pendampingan pada program ini bertujuan untuk meningkatkan pengetahuan dan pemahaman penderita diabetes tentang diet/nutrisi yang tepat dan sesuai bagi masing-masing individu, peran exersice, bagaimana praktek exersice serta pentingnya monitoring kadar gula darah sehingga nantinya dapat mengendalikan kadar gula 
darah penderita. Penyuluhan akan diawali dengan pretest kemudian pemberian materi, lalu diskusi serta ditutup degan postest. Materi dapat dibantu dengn brosur maupun pamflet serta slide power point. Penyuluhan pada mitra bersifat non formal seperti gather and sharing (berkumpul dan berbagi cerita) sehingga mitra merasa nyaman dan mampu menerima penyuluhan yang kita berikan, memahami serta nantinya mampu menerapkan pada kehidupan sehari-hari.

\subsection{Praktek/pelatihan exercise khusus pasien diabetes}

Praktek ini diberikan bagi kelompok diabetes dan petugas kesehatan sehingga nantinya mampu disalurkan pada anggota masyarakat yang lain. Pelatihan berupa pengencangan otot dengan aerobik.

Secara teknis aktifitas aerobik relatif mudah dilakukan dan tidak dibutuhkan keahlian maupun tehnik gerakan khusus seperti berjalan, berlari, bersepeda, senam dll. Sedangkan latihan pengencangan otot tergantung pada peralatan/alat bantu, pengetahuan tentang teknik latihan, dan sering membutuhkan beberapa tehnik gerakan tertentu. Untuk itu tim kemitraan masyarakat FKIK Warmadewa mendesain suatu kombinasi latihan resistance (pengencangan otot) dan aerobik dengan tehnik yang sederhana dan alat bantu yang mudah dan murah.

Pelatihan kombinasi ini terdiri dari empat gerakan yaitu: gerakan Squat, Lunges, Push Up atau Push Away dan Dumbbell Row. Gerakan ini masing-masing dilakukan sebanyak 2-3 set, 1 set dilakukan selama 10-20 menit yang bersifat gradual progresif overload (GPO). Hal ini dicapai dengan peningkatan intensitas gerakan seiring waktu, yaitu pada minggu pertama sampai empat dilakukan sebanyak 8 kali sampai 10 kali repetisi, kemudian meningkat secara gradual. Keempat gerakan ini sangat sederhana dan mampu dilakukan oleh para lansia. Hanya satu gerakan yaitu Dumbbell Row yang memerlukan alat, itu pun hanya dengan menggunakan botol air mineral ukuran $600 \mathrm{ml}$ yang berisi air sebagai barbel (pemberat). Gerakan pengencangan otot ini kemudian diikuti dengan latihan aerobik ringan seperti jalan santai, bersepeda maupun senam aerobik selama 20-30 menit. Pelatihan dilakukan setiap seminggu sekali sambil observasi kemampuan penderita dalam posisi, gerakan dan intensitas latihan fisik yang telah dilatih sebelumnya. Sedangkan monitoring, evaluasi pendampingan dilakukan 2-3 kali seminggu. Pendampingan dilakukan untuk mengobservasi, memonitoring dan mengevaluasi serta mengarahkan kegiatan sehingga penderita diabetes mampu memahami, menerapkan dan terampil dalam latihan fisik serta pengukuran kadar gula darah mandiri.

Setelah program berjalan diharapkan Kelompok Diabetes Paguyuban Rahajeng Garjita Puskesmas 1 Denpasar Barat akan mempunyai pengetahuan, wawasan dan keterampilan dalam melakukan diet dan exercise secara mandiri sehingga meningkatkan kualitas kesehatannya. Selain itu dapat menerapkan dan menyebarluaskan keterampilan tersebut bagi masyarakat sekitar terutama diwilayah Puskesmas 1 Denpasar Barat.

\section{Hasil Kegiatan.}

Pelatihan pada program ini menggunakan metode kombinasi antara latihan pengencangan otot (resistance exercise) dengan latihan aerobik (endurance exercise) serta menggunakan prinsip Gradual Progresive Overload (GPO) yang artinya semua latihan harus dilakukan secara bertahap dan dengan terjadinya peningkatan kekuatan dan kebugaran tubuh maka porsi latihan secara bertahap harus ditingkatkan. Pelaksanaan latihan fisik dengan metode kombinasi ini diikuti oleh 6 peserta yang terdiri dari penderita diabetes dan petugas puskesmas 
Denpasar Barat I. Kegiatan pelatihan ini dirasakan bermanfaat bagi penderita diabetes yang nantinya akan menjadi bekal mereka dalam melatih otot sehari-hari. Dari hasil evaluasi secara lisan dengan peserta pelatihan, didapatkan mayorits peserta (70\%) mengatakan senang dengan adanya pelatihan ini dan mengharapkan diikutsertakan kembali apabila ada pelatihan serupa.

Kegiatan pelatihan dapat dikatakan berhasil apabila dilihat dari jumlah peserta yang diikuti oleh 40 orang yang merupakan lansia dari Paguyuban Rahajeng Garjita. Paguyuban ini terdiri dari lebih dari 100 orang lansia baik yang memiliki penyakit seperti hipertensi, diabetes mellitus, asam urat, dan yang tanpa penyakit. Dari hasil observasi, 60\% peserta dapat menguasai teknik latihan fisik kombinasi walaupun performance belum sempurna. Diharapkan seiring berjalannya waktu, dapat lebih disempurnakan dan kekurangan-kekurangan dapat dihilangkan. Selain dari jumlah peserta yang melebihi target, keberhasilan program juga dapat dilihat dari pelaksanaan kegiatan yang sesuai jadwal sehingga kegiatan pelatihan telah berjalan tertib dan lancar.

Nilai rata-rata HbAlc dari 10 peserta penderita diabetes melitus yang diperiksa menunjukkan memiliki rata-rata sebesar 6,83 dan turun menjadi 6,78 \%. Diharapkan ke depannya setelah diperiksa posttest akan menunjukkan hasil yang lebih baik yaitu penurunan HbA1c.

Selain pengobatan dan injeksi insulin, salah satu pilar terapi DM untuk mencegah perkembangan penyakit tersebut adalah latihan fisik. Menurut Sherwood (2001), latihan terukur dan teratur berguna dalam penatalaksanaan diabetes melitus karena otot yang aktif bekerja tidak tergantung pada insulin. Otot yang bekerja akan menyerap dan menggunakan sebagian dari kelebihan glukosa dalam darah sehingga terjadi penurunan kebutuhan akan insulin. Latihan fisik teratur dan terukur selama 6 minggu dengan durasi waktu 30 menit, berguna dalam penatalaksanaan DM karena dapat meningkatkan produksi insulin (Huang et al, 2011; Subrata, 2018).

Menurut Riyadi dan Sukarmin (2008), latihan fisik dapat menjaga kebugaran, menurunkan berat badan dan memperbaiki sensitifitas insulin, sehingga akan memperbaiki kendali gula darah. Latihan fisik teratur (3-5 kali seminggu selama kurang lebih 30-60 menit) akan membuat otot - otot aktif bergerak. Otot - otot yang aktif akan memperbaiki sirkulasi insulin dengan cara meningkatkan dilatasi sel dan pembuluh darah sehingga membantu masuknya gula ke dalam sel. Pada otot yang aktif sensitifitas reseptor insulin pun akan meningkat sehingga pengambilan gula di pembuluh darah akan meningkat 7-20 kali lipat.

\section{Kesimpulan}

Latihan fisik dengan metode kombinasi ini mendapat tanggapan yang positif dari peserta yang terdiri dari penderita diabetes melitus dan Petugas Puskesmas Denpasar Barat I. Pelatihan ini mampu membantu sebagian penderita diabetes melitus sehingga dapat mengontrol/mengendalikan kadar gula darahnya.

\section{References}


[1] American Diabetes Association. Classification and diagnosis of diabetes. Diabetes Care. 2015;38:S8-S16. Google Scholar CrossRef.

[2] Bozkurt, N.B., Pekiner, C., dan Kellen, P. 2010. Diabetes Alters Aromatase Enzyme Levels in Gonadal Tissues of Rats. NaunynSchmiedebergs Arch Pharmacol, 382: 33-41.

[3] BPS. Badan Pusat Statistik Kota Denpasar. Perkembangan Pariwisata Bali 2015. 2017; https://denpasarkota.bps.go.id/index.php/pencarian?keywordforsearching=pariwisata\&yt1.(diaks es 10 April 2018).

[4] Dinas Kesehatan Provinsi Bali. Profil Kesehatan Provinsi Bali Tahun 2011. Denpasar : Dinas Kesehatan Provinsi Bali 2012 [Diakses 10 April 2017]. Available from URL: HIPERLINK http://www.diskes.baliprov.go.id/files/subdomain/diskes/Profil\%20Kesehatan\%20Provinsi $\% 20$ Bali/Tahun\%202011/Bali_Profil 2011.pdf

[5] Guyton and Hall. 2011. Textbook of Medical Physiology twelfth edition. Philadelphia: Saunders Elsevier.

[6] Huang, Q., Wang, T., Lu, W., Mu, P., Yang, Y., Liang, W., Li, C., dan Lin, G. 2006. Estrogen Receptor Alpha Gene Polymorphism Associated With Type 2 Diabetes Melitus and The Serum Lipid Concentration in Chinese Women in Guangzhou. Chin Med J; 119 (21): 1794-1801.

[7] Pemerintah Kota Denpasar. Denpasar. 2017. [Diakses 11 April 2017]. Available from URL: HIPERLINK http://geoportal.denpasarkota.go.id

[8] Riyadi dan Sukarmin. 2008. Asuhan Keperawatan pada Pasien dengan Gangguan Eksokrin dan Endokrin pada Pankreas. Yogyakarta. Graha Ilmu.

[9] Sherwod, P. 2001. Fisiologi Manusia: Dari Sel ke Sistem. Jakarta: EGC

[10] Subrata, T., Lestarini, A., Sari, K., 2018. Physical Exercises Effectiveness in Controlling Diabetes Mellitus in the Elderly Group in Bali - Indonesia IOP Conf. Ser.: Mater. Sci. Eng. 434 012228 